\title{
Harnessing the potentials of millet production for food defense and economic diversification in Nigeria
}

Nijerya'da gıda savunması ve ekonomik çeşitlendirme için darı üretiminin potansiyellerinden yararlanmak

\author{
Mohammed Sanusi SADIQ ${ }^{1 \mathscr{O}}$ (D), Invinder Paul SINGH ${ }^{2}$, Muhammad Makarfi AHMAD $^{3}$ (iD \\ ${ }^{1}$ Department of Agricultural Economics and Extension, FUD, Dutse, Nigeria. \\ ${ }^{2}$ Department of Agricultural Economics, SKRAU, Bikaner, India. \\ ${ }^{3}$ Department of Agricultural Economics, BUK, Kano, Nigeria.
}

MAKALE BILGISI / ARTICLE INFO

Makale tarihçesi / Articlehistory:

DOI: $10.37908 /$ mkutbd.778784

Geliş tarihi /Received:10.08.2020

Kabul tarihi/Accepted:06.07.2021

\section{Keywords:}

Growth, trend, production, forecast, millet, Nigeria.

\footnotetext{
Correspondingauthor: M.S. SADIQ

$\bowtie:$ sadiqsanusi30@gmail.com
}

\section{ÖZET / A B S T R A C T}

Atıf / Citation: Sadiq MS, Singh IP, Ahmad MM (2021) Harnessing the potentials of millet production for food defense and economic diversification in Nigeria. MKU. Tar. Bil. Derg. 26(2) : 471-488. DOI: 10.37908/mkutbd.778784

\begin{abstract}
Aims: Millet has the potential to become important components of intensive agriculture especially in Nigeria, hence the need to explore its food security and economic diversification potentials.

MethodsandResults: Time series data that spanned from 1961 to 2018 sourced from FAO database, covering production, area and yield were used to examine the food security trend of millet production in Nigeria. The collected data were analyzed using both descriptive and inferential statistics. The finding showed poor performance in the production of millet as growth was driven by area other than productivity. It was observed that price volatility triggered high fluctuation in area and yield, thus causing high instability in the production of millet. In addition, production risk and uncertainty were the major sources of production variability between the regime shifts. It was observed that surge in the average production level between regime shifts owed majorly to area expansion. The empirical evidence showed that the farmers decision on current acreage allocation for millet was governed by both institutional and non-institution factors. Furthermore, the forecast showed that the country will be faced with millet food insecurity to battle with; as critical reliance on millet importation will expose the country to risks from global food price spikes and shortages; and geopolitical and environmental threats.

Conclusions: Thus, it can be inferred that the growth performance of millet production is not favorable. In lieu, the study recommends the need for long-term domestic self-sufficiency in millet production capable of feeding the country's population as a key strategic food goal.

SignificanceandImpact of theStudy: Therefore, the outcome of this research will serve as leverage/ leeway for policy makers towards addressing the challenges of millet production for food security, stimulating livestock production-animal feed and foreign earning viz. exportation to the abundant arid regions in the sub-Saharan Africa.
\end{abstract}




\section{INTRODUCTION}

Millets are a group of highly variable small-seeded grasses which are widely grown around the world as cereal crops or food grains for human food and fodder. Millets have been an important staple food in human history particularly in Asia and Africa (Isah et al., 2019). For the last 10000 years, they have been in cultivation in East Asia (Lu et al. 2009). For some 7,000 years the crop may have been consumed by humans and potentially had "a pivotal role in the rise of multi-crop agriculture and settled farming societies.

Millets are significant crops in Asia and Africa's semiarid tropics particularly in India, Mali, Nigeria and Niger; with 97 percent of the production being in developing countries. The crop is preferred due to its productivity and limited growing season under warm, hightemperature conditions. Pearl millet is one of the two main crops in the African and Southeast Asian semiarid, impoverished, less fertile agricultural regions. They are highly tolerant of drought and other harsh weather conditions, and have similar nutrient content as maize and sorghum to other major cereals. Millets are not only adapted to poor, droughty and infertile soils, but are also more reliable than most other grain crops under these conditions (Isah et al., 2019; Scene Agric, 2020). This has made the crop's production famous, especially in West African countries surrounding the Sahara.

Global millet production was 28.4 million tons in 2016, led by India with 36 percent of the world's total; Niger also had significant annual output of 3.9 million metric tons. Nigeria is the world's fifth largest producer of millet with an annual tonnage of 1.5 million tons in 2016 (FAO , 2018). Millet is an important food item for the population living in the drier sections of many other countries, especially in East and Central Africa, and in West Africa's northern coastal countries. In developing countries outside Africa, in parts of some countries, such as China, India, Burma and North Korea (Scene Agric, 2020), millet has local significance as a food. Millets are commonly used in the production of beverages and can also act as a food source worldwide. While millet accounts for less than 2 percent of world cereal use, it is a significant staple food in the semi-arid tropicsin a large number of countries where low precipitation and poor soils restrict the cultivation of other major food crops. Millet's highest use is in West Africa, and the use is largely limited to the developing world.

In Africa, the primary demand for millets is for food, particularly in the dry-land regions where it is a main crop. This continuing demand is reflected in the trend over the last fifty years to increase area under millet in Africa, but crop productivity has not kept up with this increasing demand (Ali et al., 2018). As of 2016, Nigeria recorded an annual tonnage of 1.468 .668 million compared to 2008, reporting the highest tonnage of 9.064.000 million and lowest in 2003, which was 909.560 thousand tons.

Recently, 97 per cent of the world's demand for millet and seed comes from developing countries. India is the world's largest millet producer with the highest demand for millet seeds, followed by Nigeria, Niger, China and Mali. For countries like India and Africa, where food and nutrition availability are major challenges, millets are the way forward (Anonymous, 2018a). Scene Agric (2020) reported that by the end of 2022 , the global millet market is expected to be worth more than $\$ 13$ million. Global millet market growth is primarily tied to different macroeconomic and microeconomic factors. The millet sales are expected to remain strong and are due to growing consumer demand for nutritious and fibre-dense food items. As consumers are more aware of nutritious food products and tend to adopt a healthier lifestyle, leading food industry companies are focusing on providing food products based on millet worldwide. In addition to food products, millets also continue to witness considerable demand for malted and alcoholic beverage products. Restricted access to water supplies will continue to dramatically boost millet sales in the semi-arid regions (Anonymous, 2018b). In view of the above, it can be inferred that the crop has the potential to become important components of intensive agriculture especially in Nigeria, hence the need to explore its food security and economic diversification potentials. The specific goals were to examine the trend in production and the growth pattern of millet production; to determine the extent and magnitude of production instability; to determine the sources of production change; to determine the factors influencing the decision to allocate the acreage of farmers; and to forecast the trend in production of millet in Nigeria.

\section{MATERIALS and METHODS}

Collected time series data from FAO database that spanned from 1961 to 2018, covering production, area, yield and prices were used for this study. The study examined the millet production viz. three regime shifts vis-à-vis pre-Structural Adjustment Period (preSAP)(1961-1984), SAP (1985-1999) and post-SAP(20002018). The collected data were analyzed using both 
descriptive and inferential statistics. The above specified objectives in descending order were achieve using descriptive statistics and compound growth model; instability index and Hazell's decomposition model; instantaneous and Hazell's decomposition models; Nerlove's distributed lag model; and, ARIMA model respectively.

\section{Model specification}

Growth rate: The compound annual growth rate calculated using the exponential model is given below:

$\gamma=\alpha \beta^{t}$

$\ln \gamma=\ln \alpha+\operatorname{tn} \beta$

CAGR $=[$ Antilog $\beta-1] \times 100$

Where, CAGR is compound growth rate; $t$ is time period in year; $\gamma$ is area/yield/production; $\alpha$ is intercept; and, $\beta$ is the estimated parameter coefficient.

Instability index: Coefficient of variation (CV), CuddyDella Valle Index (CDII) and Coppock's index were used to measure the variability in the production, area and yield.

$C V(\%)=\frac{\sigma}{\bar{X}} * 100$

(4) (Sandeep et

al., 2016; and Boyal et al., 2015)

Where, $\sigma$ is standard deviation and $\bar{X}$ is the mean value of $\mathrm{CDII}=\mathrm{CV} *\left(1-\mathrm{R}^{2}\right)^{0.5}$

Where CDII is the Cuddy-Della instability index; CV is the coefficient of variation; and, $R^{2}$ is the coefficient of multiple determination (Cuddy-Della Valle, 1978). The instability index classification is low instability $(\leq 20 \%)$, moderate instability (21-40\%) and high instability (>40\%) (Shimla, 2014; and Umar et al., 2019).

Unlike CV, Coppock's instability index give close approximation of the average year-to-year percentage variation adjusted for trend (Coppock, 1962; Ahmed and Joshi, 2013; Kumar et al., 2017; Umar et al., 2019).

$C I I=(\operatorname{Antilog} \sqrt{\log V}-1) *$ 100

$\log V=\frac{\sum\left[\log \frac{X_{t+1}}{X_{t}}-m\right]^{2}}{N-1}$
Where, $X_{t}=$ Area or Yield or Production in year ' $t$ ', $N=$ number of year $(s), \mathrm{Cll}=$ Coppock's instability index; $m=$ mean difference between the $\log$ of $X_{t+1}$ and $X_{t}$; and, $\log V=$ Logarithm Variance of the series

\section{Source of change in production}

Instantaneous change: The instantaneous decomposition model as used by Sandeep et al. (2016) is given below:

$P_{0}=A_{0} \times Y_{0}$

$P_{n}=A_{n} \times Y_{n}$

Where, $P, A$ and $Y$ represent the production, area and yield respectively. The subscript 0 and $n$ represent the base and the $n^{\text {th }}$ years respectively.

$P_{n}-P_{0}=\Delta P$

$A_{n}-A_{0}=\Delta A$

$Y_{n}-Y_{0}=\Delta Y$

From equation (5) and (9) we can write

$P_{0}+\Delta P=\left(A_{0}+\Delta A\right)\left(Y_{0}+\Delta Y\right)$

Therefore,

$P=\frac{Y_{0} \Delta A}{\Delta P} \times 100+\frac{A_{0} \Delta Y}{\Delta P} \times 100+\frac{\Delta A \Delta Y}{\Delta P} \times 100$

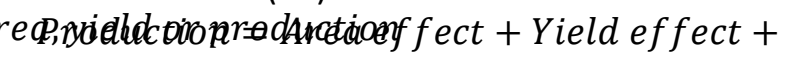

Interaction effect

Hazell's decomposition model: Following Hazell's (1982) as adopted by Umar et al.(2017; 2019), the model is presented below:

\section{i. $\quad$ Changes in average production}

$E(P)=\bar{A} \bar{Y}+\operatorname{COV}(A, Y)$

$\Delta E(P)=E\left(P_{2}\right)-E\left(P_{1}\right)=\bar{A}_{1} \Delta \bar{Y}+\bar{Y}_{1} \Delta \bar{A}+\Delta \bar{A} \Delta \bar{Y}+$ $\triangle \operatorname{COV}(A, Y)$ (14)

ii. Change in variance decomposition: $V(P)=\bar{A}^{2} \cdot V(Y)+\bar{Y}^{2} \cdot V(A)+2 \bar{A} \bar{Y} \operatorname{COV}(A, Y)-$ $\operatorname{COV}(A, Y)^{2}+R$ 
Table 1. Components of change in the average production

\begin{tabular}{lcc}
\hline Sources of change & Symbols & Components of change \\
\hline Change in mean area & $\Delta \bar{A}$ & $\overline{A_{1}} \Delta \bar{Y}$ \\
Change in mean yield & $\Delta \bar{Y}$ & $\bar{Y}_{1} \Delta \bar{A}$ \\
Interaction effect & $\Delta \bar{A} \Delta \bar{Y}$ & $\Delta \bar{A} \Delta \bar{Y}$ \\
Changes in area-yield covariance & $\Delta \operatorname{COV}(A, Y)$ & $\Delta \operatorname{COV}(A, Y)$ \\
\hline
\end{tabular}

Table 2. Components of change in variance production

\begin{tabular}{|c|c|c|}
\hline Sources of change & Symbols & Components of change \\
\hline Change in mean area & $\Delta \bar{A}$ & $2 \bar{Y} \Delta \bar{A} \operatorname{COV}(A, Y)+\left\{2 \bar{A} \Delta \bar{A}+(\Delta \bar{A})^{2}\right\} V(Y)$ \\
\hline Change in mean yield & $\Delta \bar{Y}$ & $2 \bar{A} \Delta \bar{Y} \operatorname{COV}(A, Y)+\left\{2 \bar{Y} \Delta \bar{Y}+(\Delta \bar{Y})^{2}\right\} V(A)$ \\
\hline Change in area variance & $\Delta V(A)$ & $\bar{Y}^{2} V(A)$ \\
\hline Change in yield variance & $\Delta V(Y)$ & $\bar{A}^{2} V(Y)$ \\
\hline $\begin{array}{l}\text { Interaction effect I (changes in } \\
\text { mean area and mean yield) }\end{array}$ & $\Delta \bar{A} \Delta \overline{\bar{Y}}$ & $2 \Delta \bar{A} \Delta \bar{Y} \operatorname{COV}(A, Y)$ \\
\hline Changes in area-yield covariance & $\Delta \operatorname{COV}(A, Y)$ & $\{2 \bar{A} \bar{Y}-2 \operatorname{COV}(A, Y)\} \operatorname{COV}(A, Y)-\{\Delta \operatorname{COV}(A, Y)\}^{2}$ \\
\hline $\begin{array}{l}\text { Interaction effect II (changes in } \\
\text { mean area and yield variance) }\end{array}$ & $\Delta \bar{A} \Delta V(Y)$ & $\left\{2 \bar{A} \Delta \bar{A}+(\Delta \bar{A})^{2}\right\} \Delta V(Y)$ \\
\hline $\begin{array}{l}\text { Interaction effect II (changes in } \\
\text { mean yield and area variance) }\end{array}$ & $\Delta \bar{Y} \Delta V(A)$ & $\left\{2 \bar{Y} \Delta \bar{Y}+(\Delta \bar{Y})^{2}\right\} \Delta V(A)$ \\
\hline $\begin{array}{l}\text { Interaction effect IV (changes in } \\
\text { mean area and mean yield and } \\
\text { changes in area-yield covariance) }\end{array}$ & $\Delta \bar{A} \Delta \bar{Y} \operatorname{COV}(A, Y)$ & $(2 \bar{A} \Delta \bar{Y}+2 \bar{Y} \Delta \bar{A}+2 \Delta \bar{A} \Delta \bar{Y}) \Delta \operatorname{COV}(A, Y)$ \\
\hline Residual & $\Delta R$ & $\Delta V(A Y)$ \\
\hline
\end{tabular}

Nerlovian's model: The Nerlove's response model as used by Sadiq et al.(2017) is presented below:

$A_{t}^{*}=\beta_{0}+\beta_{1} M P_{t-1}+\beta_{2} S P_{t-1}+\beta_{3} M L P_{t-1}+$ $\beta_{4} M P R_{t-1}+\beta_{5} S P R_{t-1}+\beta_{6} M L P R_{t-1}+\beta_{7} Y_{t-1}+$ $\beta_{8} Y R_{t-1}+\beta_{9} W I_{t}+\beta_{10} T_{t}+\beta_{11} A_{t-1}+\varepsilon_{t}$

The first equation is a behavioural equation, stating that desired acreage $\left(A_{t}^{*}\right)$ depend upon the following independent variables:

Where,

$A_{t}=$ current area under millet;

$M P_{t-1}=$ one year lagged price of maize;

$S P_{t-1}=$ one year lagged price of sorghum;

$M L P_{t-1}=$ one year lagged price of millet;

$M P R_{t-1}=$ one year lagged price risk of maize;

$S P R_{t-1}=$ one year lagged price risk of sorghum;

$M L P R_{t-1}=$ one year lagged price risk of millet;

$Y_{t-1}=$ one year lagged yield of millet;

$Y R_{t-1}=$ one year lagged yield risk of millet;

$W I_{t}=$ weather index for rice;

$T_{t}=$ time trend at period $t ;$

$A_{t-1}=$ one year lagged area under millet;

$\beta_{0}=$ intercept;

$\beta_{1-n}=$ parameter estimates; and,

$\varepsilon_{t}=$ Disturbance term.
Price and yield risks were measured by the standard deviation of the three preceding years. For the weather index, the impact of weather on yield variability was measured with a Stalling's index (Stalling, 1960; Ayalew, 2015).

The number of years required for 95 percent of the effect of the price to materialize is given below (Sadiq et al., 2017):

$(1-r)^{n}=0.05$

Where;

$r=$ coefficient of adjustment (1-coefficient of lagged area); and,

$\mathrm{n}=$ number of year.

Marginal effect and price elasticities for exponential functional form are given below:

$M E=$ coefficient $*$ mean of current area

SRE $=$ coefficient $*$

mean of current predictor $(s)$

$L R E=\frac{S R E}{\text { Coefficient of adjustment }}$ 


\section{ARIMA}

ARIMA in general form is as follows (Gujarati et al., 2012):

$\Delta^{d} Z_{t}=\alpha+\left(\delta_{1} \Delta^{d} Z_{t-1}+\cdots . .+\delta_{p} \Delta^{d} Z_{t-p}\right)-$

$\left(\varphi_{1} \varepsilon_{t-1}+\cdots . .+\varphi_{q} \varepsilon_{t-q}\right)+\varepsilon_{t} \ldots \ldots \ldots . .(21)$

Where, $\Delta$ denotes difference operator like:

$\Delta Z_{t}=Z_{t}-Z_{t-1}$

$\Delta^{2} Z_{t-1}=\Delta Z_{t}-\Delta Z_{t-1}$

Here, $Z_{t-1} \ldots \ldots \ldots, Z_{t-p}$ are values of past series with $\operatorname{lag} 1$, $p$ respectively.

\section{Forecasting Accuracy}

For measuring the accuracy in fitted time series model, mean absolute prediction error (MAPE), relative mean square prediction error (RMSPE), relative mean absolute prediction error (RMAPE) (Paul, 2014), Theil's $U$ statistic and $R^{2}$ were computed using the following formulae:

$M A P E=1 / T \sum_{i=1}^{5}\left(A_{t-1}-F_{t-1}\right)$

$R M P S E=1 / T \sum_{i=1}^{5}\left(A_{t-1}-F_{t-1}\right)^{2} / A_{t-}$

$R M A P E=1 / T \sum_{i=1}^{5}\left(A_{t-1}-F_{t-1}\right) / A_{t-1} \times$

100.

$U=\sqrt{\frac{\sum_{t=1}^{n-1} \frac{\left(\widehat{P}_{t+1}-Y_{t+1}\right)^{2}}{Y_{t}}}{\sum_{t=1}^{n-1} \frac{\left(Y_{t+1}-Y_{t}\right)^{2}}{Y_{t}}}}$

$R^{2}=1-\frac{\sum_{i=1}^{n}\left(A_{t i}-F_{t i}\right)}{\sum_{i=1}^{n}\left(A_{t i}\right)}$

Where, $R^{2}=$ coefficient of multiple determination, $A_{t}=$ Actual value; $F_{t}=$ Future value, and $\mathrm{T}=$ time period

\section{RESULTS and DISCUSSION}

\section{Trend and growth patterns of millet production}

The diagrammatical framework showed the production trend to be marked by marginal fluctuating changes which majorly owed to marginal fluctuating changes in area during the pre-SAP period. From 1961 to 1966, the production trend exhibits a cyclical trend owing to a pronounced similar trend exhibited by area as yield declined between the periods except in year 1963 . From 1967 to 1970, the production trend increased due to pronounced effect of area expansion as yield declined through the periods except in year 1969 where it marginally inclined and afterward plummeted. A steep decline in area despite an increase in yield forced the production trend to sharply fall from 1971 to 1972.
In other words, between 1967 and 1972, the pronounced cyclical trend behavior of area as changes in yield was marginal made the production trend to exhibit a cyclical trend with trough points in 1967 and 1972; and, peak point in 1969. Afterward, a sharp cyclical trend due to both increased area and yield made the production trend to increase steeply from year 1973; peaked at year 1974, and thereafter steeply plummeted till year 1978. Furthermore, in the immediate succeeding period (1979), the production trend gently inclined, thereafter declined gently; and afterward a recovery in the production trend in year 1981 that marginally increased till the end of the study period. The trend behavior of production owed to the pronounced effect of changes in area as almost stagnant trend marked the yield (Figure 2).

During the SAP period, the production trend exhibited a cyclical trend from 1985 to 1991; troughed in 1985, 1988 and 1991; and, peaked in 1986 and 1999. The first cyclical trend was marginal while the succeeding one was gentle. This production trend was governed by both area and yield but the effect of area was more pronounced. The plummeted production in 1991 steeply increased thereafter and maintained an increasing trend till the end of the study period. The steep increase in area expansion was the major driving force behind the production trend as yield plummeted and later became stagnant (Figure 3). It was observed that during the post-SAP period, the production trend marginally plummeted from year 1999 to year 2000; and thereafter, the production trend steeped upward till year 2008 owing majorly to a steep increase in yield as area expanded marginally. Afterward, the production trend of millet steeply plummeted owing to a steep fall in both area and yield, and thereafter a recovery trend in the production surfaced in year 2010 due to slight expansion in the area as yield trend declined. Subsequently, the production trend of millet steeply declined in year 2011 due to a steep fall in both area and yield; and afterward increased and decreased slightly from year 2012 to year 2013. A marginal recovery trend marked the production of millet from year 2014 with an incremental marginal change till the end of the study period which owed majorly to the pronounced effect of marginal expansion in area as yield was marked by plummeting and stagnant changes (Figure 4). 


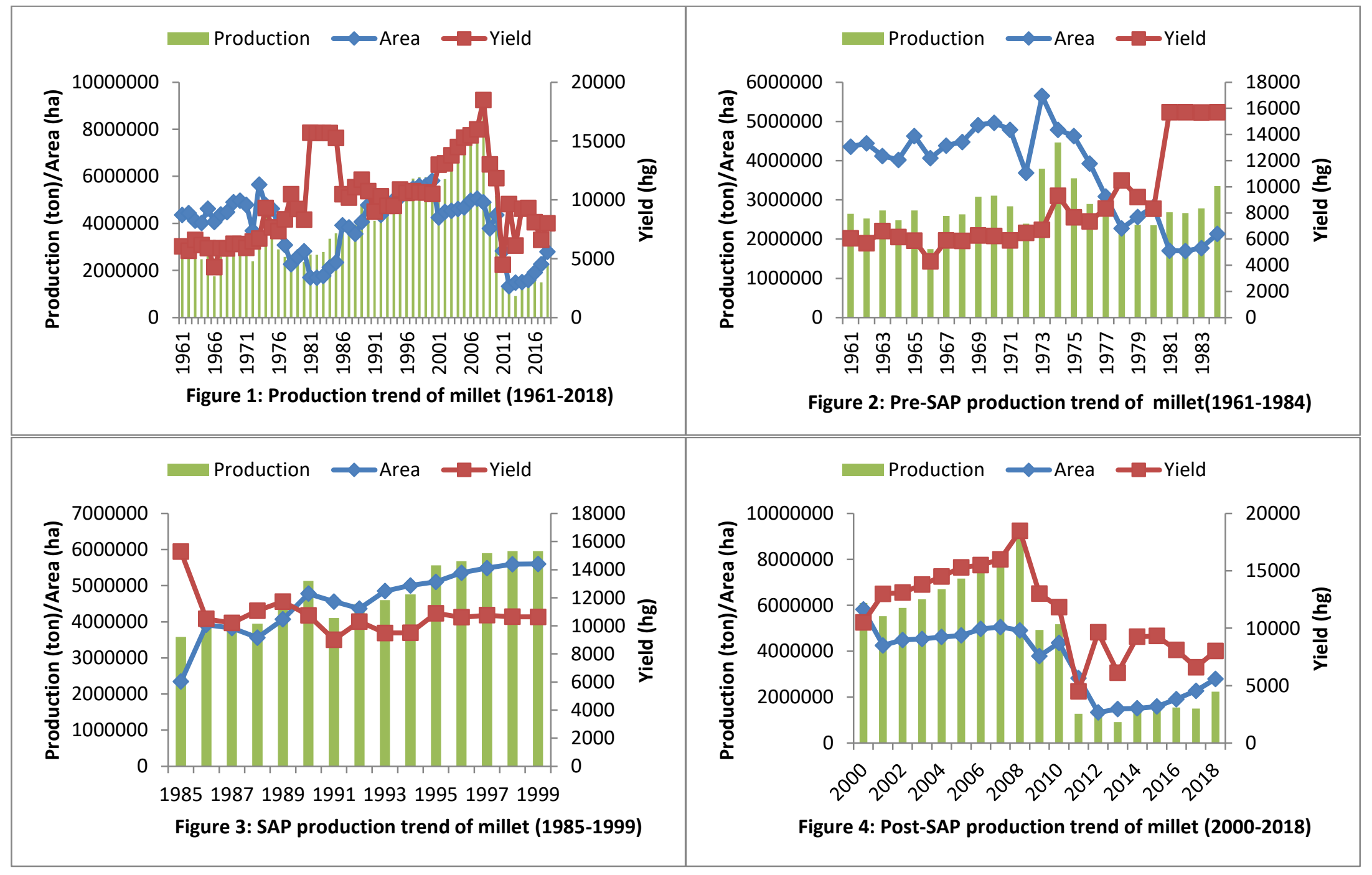


A cursory review of the average annual production of millet vis-à-vis the regime periods showed a sharp increase in production by two-fold from 2.8 million MT during the pre-SAP period to 4.8 million MT during the SAP period; and, thereafter it gently plummeted to 4.4 million MT during the post-SAP period. It was observed that increase in both area and yield from pre-SAP to SAP was responsible for the steep increase in production between the two periods while pronounced decline in area despite increase in the productivity of yield was majorly responsible for the gentle decline in the production of millet between SAP period and postSAP regime (Table 3 ).

Furthermore, the production of millet witnessed a positive insignificant growth rate during the pre-SAP period while it witnessed significant positive and negative growth rate during the SAP and post-SAP regimes respectively. It was observed that area was marked by a negative significant growth rate during the pre-SAP and post-SAP periods; a positive growth rate during the SAP period. The yield witnessed a significant positive growth during the pre-SAP era; a negative insignificant growth rate during the SAP period; and, a negative significant growth rate during the post-SAP regime. For the overall period, positive insignificant growth rate marked the production of millet while negative and positive significant growth rates marked the area and yield of millet in the studied area (Table 3 ). Therefore, it can be inferred that the insignificant growth rate of production during the pre-SAP era owed solely to decline in the growth rate of area despite increase in the growth rate of yield during the same period. Also, during the SAP period, increased in the growth rate of production owed solely to increase in area growth rate as annual growth in yield was stagnant. However, both increase in area and yield growth rates were responsible for the increased growth rate which marked production of millet during the postSAP regime.

It was observed that the annual growth rate of millet production sharply increased from $0.5 \%$ during the preSAP to $3.5 \%$ during the SAP period; and suddenly, it steeply plummeted to $-11.1 \%$ during the post-SAP era. The area, from the trough steeply increased to $4.6 \%$ from $-4.0 \%$ during the pre-SAP and SAP periods respectively; and suddenly, it steeply declined to $-6.9 \%$ during the succeeding regime. However, it was observed that the yield steeply plummeted from $4.6 \%$ during the pre-SAP period to $-1.0 \%$ during the SAP era; and further declined to $-4.2 \%$ during the post-SAP period (Table 3). Therefore, it can be inferred that the growth rate in the production of millet vis-à-vis the regime shifts was due to the changes in the growth rate of both area and yield but the effect of area was more pronounced.

The empirical evidence showed that if the pre-SAP and post-SAP regimes production growth rates are doubled, their respective production growth rates will stagnant and accelerate respectively. However, doubling of the production growth rate during the post-SAP and the overall regimes will lead to deceleration in the growth rate (Table 3 ).

Table 3. Growth pattern of millet production

\begin{tabular}{llllll}
\hline Variables & & Pre-SAP & SAP & Post-SAP & Overall \\
\hline Area (ha) & CGAR $\%$ & $96.1^{* * *}$ & $104.6^{* * *}$ & $93.3^{* * *}$ & $99.4^{* *}$ \\
& AGR \% & $-4.0^{* * *}$ & $4.6^{* * *}$ & $-6.9^{* * *}$ & $-0.6^{* *}$ \\
& AA & 3746375 & 4562200 & 3537236 & 3888853 \\
& Status & $-13207.82^{* * *}(\mathrm{D})$ & $-9387.60^{* * *}(\mathrm{D})$ & $-1272.41^{* * *}(\mathrm{D})$ & $-1105.765^{*}(\mathrm{D})$ \\
Yield (hg) & CGAR $\%$ & $104.6^{* * *}$ & $99.0^{\mathrm{NS}}$ & $95.9^{* * *}$ & $101.0^{* * *}$ \\
& AGR\% & $4.6^{* * *}$ & $-1.0^{\mathrm{NS}}$ & $-4.2^{* * *}$ & $0.9^{* * *}$ \\
& AA & 8405.167 & 10758.33 & 11401.63 & 9995.345 \\
& Status & $36.757^{* * *}(\mathrm{~A})$ & $46.64^{* *}(\mathrm{~A})$ & $-44.01^{* * *}(\mathrm{D})$ & $-7.295^{* * *}(\mathrm{D})$ \\
Production & CGAR \% & $100.5^{\mathrm{NS}}$ & $103.5^{* * *}$ & $89.5^{* * *}$ & $100.3^{\mathrm{NS}}$ \\
(ton) & AGR\% & $0.5^{\mathrm{NS}}$ & $3.5^{* * *}$ & -11.1 & $0.3^{\mathrm{NS}}$ \\
& AA & 2806458 & 4832400 & 4433915 & 3863541 \\
& Status & $-3225.57^{\mathrm{NS}}(\mathrm{S})$ & $4249.59^{* * *}(\mathrm{~A})$ & $-21667.86^{* * *}(\mathrm{D})$ & $-3517.248^{* * *}(\mathrm{D})$ \\
\hline
\end{tabular}

Source: Authors' computation, 2020; ******\&NS means significant at 1, 5, 10\% and Non-significant respectively.

Note: CGR- Compound growth rate; AGR- Annual growth rate; AA- Annual Average; A- Acceleration; D- Deceleration; SStagnation. 


\section{Magnitude of instability in millet production}

The CV index showed the production of millet during the pre-SAP and SAP regimes to be marked by a low instability inspite of moderate and low instabilities in both area and yield respectively (Table 4). However, it is surprising that inspite of the moderate fluctuation in both area and yield during the pre-SAP regime, the production instability was low but the $\mathrm{CV}$ value (19.67\%) was close to the border region of moderate instability. Furthermore, high instability owing to a moderate fluctuation in both area and yield marred the production of millet during the post-SAP period. While for the overall period, intermittent moderate instability in both area and yield caused the production instability to be moderate. It can be suggested that millet production witnessed more of moderate instability in the country.

In examining the direction of instability in the production of millet, the CDII index showed production to be marked by a low instability during the pre-SAP regime owing to a mild moderate instability in both area and yield (Table 4). This trend was similar to the instability results revealed by the $\mathrm{CV}$ index for millet production during the pre-SAP era. The intermittent low instability in both area and yield made millet production to witness a low instability. Also, the intermittent moderate instability in both area and yield forced millet production to witness a moderate instability. However, it was observed that both area and yield exhibited a moderate instability during the overall period but production witnessed a high instability. Generally, it can be suggested that area expansion and serial introduction of innovations viz. improved seed varieties were responsible for the shocks that marked the production of millet in the country.

A review of the price transmission effect on production instability viz. year-to-year, the $\mathrm{Cll}$ index showed millet production to be marked by a high variability owing to a high fluctuation in both area and yield (Table 4). However, the effect of area variability was more pronounced across the regime shifts which owed to more of area expansion that the use of improved seed varieties. Therefore, it can be inferred that low supply which could not shore-up the high demand generated price shock which affected millet production in the country.

Table 4. Magnitude of instability in millet production (\%)

\begin{tabular}{lllll}
\hline Regimes & Variables & CV & CDII & CII \\
\hline Pre-SAP & Area & 32.745 & 20.39455 & 53.44902 \\
& Yield & 34.938 & 22.13194 & 53.37251 \\
SAP & Production & 48.948 & 19.34371 & 44.31973 \\
& Area & 31.507 & 9.733917 & 46.27343 \\
& Yield & 42.912 & 12.28418 & 41.45105 \\
Post-SAP & Production & 19.671 & 7.148767 & 43.66139 \\
& Area & 19.787 & 26.33291 & 60.62832 \\
& Yield & 13.231 & 25.91361 & 53.47652 \\
Overall & Production & 16.992 & 39.57666 & 81.97851 \\
& Area & 41.793 & 31.61207 & 55.24336 \\
& Yield & 33.371 & 31.22996 & 52.61573 \\
& Production & 62.971 & 48.67804 & 61.99852 \\
\hline
\end{tabular}

Source: Authors' computation, 2020

Furthermore, between the regime shifts, a cursory review of the results showed "change in area yield covariance" and "change in residual" to be the major sources of production variability for between the preSAP and SAP regimes; and the overall period (Table 5). However, the effect of "change in area yield variance' was more pronounced in the case of the former while "change in residual" was more pronounced in the case of the latter. Between the SAP and post-SAP regimes, production variance owes majorly to "change in area variance". Therefore, it can be inferred that area risk, technology risk and uncertainty viz. uneven weather patterns marred millet production in the country.

\section{Sources of changes in millet production}

A cursory review of the instantaneous changes in the average production of millet vis-à-vis the regime shifts showed that during the pre-SAP period, "yield effect" caused an incremental change in the average annual production level while "area effect" and "interaction effect" decreased the average production level (Table 6). Furthermore, during the SAP period, "area effect" was the only factor responsible for incremental changes 
in the average production level as both "yield effect" and "interaction effect" exhibited plummeted effect on the average annual production level. During the postSAP regime, incremental change in the average annual production owed majorly to "area effect" as "yield effect" was marginal while "interaction effect" caused decrease in the annual average production level. Therefore, apart from the pre-SAP period, it can be inferred that the change in the annual average production level of millet across the regime shifts was majorly driven by area expansion at the expense of productivity. For the overall period, "interaction effect" was the sole factor responsible for change in the average annual production as both "area effect" and "yield effect" were observed to decrease the annual average production level.

Table 5. Sources of instability in millet production

\begin{tabular}{|c|c|c|c|}
\hline Source of variance & Pre-SAP to SAP & SAP to Post-SAP & Overall \\
\hline Change in mean yield & -617.15 & -21.16 & -161.08 \\
\hline Change in mean area & 132.01 & 4.50 & 64.46 \\
\hline Change in yield variance & -607.70 & -4.22 & -99.15 \\
\hline Change in area variance & -32.24 & 60.99 & 1.77 \\
\hline $\begin{array}{l}\text { Interaction between changes in mean yield and } \\
\text { mean area }\end{array}$ & -48.11 & 0.37 & -141.44 \\
\hline Change in area yield covariance & 683.46 & 27.61 & 144.75 \\
\hline $\begin{array}{l}\text { Interaction between changes in mean area and } \\
\text { yield variance }\end{array}$ & -293.49 & 1.68 & 91.73 \\
\hline $\begin{array}{l}\text { Interaction between changes in mean yield and } \\
\text { area variance }\end{array}$ & -20.58 & 7.51 & -1.76 \\
\hline $\begin{array}{l}\text { Interaction between changes in mean area and } \\
\text { yield and change in area-yield covariance }\end{array}$ & 366.47 & -4.90 & -143.50 \\
\hline Change in residual & 537.33 & 27.62 & 344.22 \\
\hline Total change in variance of production & 100.00 & 100.00 & 100.00 \\
\hline
\end{tabular}

Source: Authors' computation, 2020

Table 6. Instantaneous source(s) of change in millet production (Intra-wise \%)

\begin{tabular}{lllll}
\hline Source of change & Pre-SAP & SAP & Post-SAP & Overall \\
\hline Area effect & -205.295 & 180.8654 & 87.05759 & -11.1044 \\
Yield effect & 477.5896 & -46.0103 & 24.20658 & -290.574 \\
Interaction effect & -172.278 & -34.8582 & -11.2598 & 401.6267 \\
Total change & $\mathbf{1 0 0}$ & $\mathbf{1 0 0}$ & $\mathbf{1 0 0}$ & $\mathbf{1 0 0}$ \\
\hline
\end{tabular}

Source: Authors' own computation, 2020

Furthermore, between the regime shifts, it was observed that "change in mean yield" and "change in mean area" were the major driven forces which made the average annual production during the SAP period to be higher than that of the pre-SAP period (Table 7). The effect of the former was more pronounced than that of the latter. Though, "interaction between the mean area and yield" and "change in yield and area covariance" had increased the average annual production but their effects were marginal. Between the SAP and post-SAP regimes, "change in mean area" was the dominant factor responsible for the average annual production of post-SAP era to be higher than that of the SAP regime as "interaction between mean area and mean yield" had marginal effect on the incremental change. Therefore, it can be inferred that area expansion predominates in causing incremental change in millet production between periods in the studied area. 
Table 7. Sources of change in millet production (Inter-regime wise \%)

\begin{tabular}{lll}
\hline Source of change & Pre-SAP to SAP & SAP to Post-SAP \\
\hline Change in Mean yield & 45.28 & -35.06 \\
Change in Mean Area & 35.22 & 131.74 \\
Interaction between Changes in mean area and mean yield & 9.86 & 7.88 \\
Change in yield and area covariance & 9.65 & -4.56 \\
Total change & $\mathbf{1 0 0}$ & $\mathbf{1 0 0}$ \\
\hline
\end{tabular}

Source: Authors' computation, 2020

\section{Farmers' acreage response}

Among the estimated functional forms, the OLS estimation showed the exponential functional form to be the best fit for the specified equation as it satisfied the economic, statistical and econometric criteria (Table $8 \& 9$ ). The results of the diagnostic test indicates that the residual is normally distributed and has no problem of heteroscedasticity, serial correlation and Arch effect as evident by their respective t-statistics which were not different from zero at $10 \%$ degree of freedom. In addition, the empirical evidence indicated that the functional form is adequately specified and the estimated parameters are stable as revealed by the RESET and CUSUM tests statistics which were not different from zero at $10 \%$ probability level, respectively. The non-significant of the Chow-test indicated absence of structural break in the data, thus the data is treated as one population and not subpopulation. The Durbin-Watson (DW) statistic been greater than the coefficient of multiple determination $\left(R^{2}\right)$ indicates absence of a spurious correlation; likewise, the reasonable value of $R^{2}(0.8813)$ revealed absence of a spurious regression. Thus, it can be inferred that the parameter estimates are reliable for future prediction with certainty and consistency.

The $R^{2}$ value of 0.8813 implies that $88.13 \%$ of the variation in the acreage response of the farmers was influenced by the actual economic phenomena included in the model while disturbed economic reality accounted for $11.87 \%$. The variables found to have significant impact on the farmers' acreage response were lagged yield, weather index, lagged price of maize, lagged price of millet, lagged yield risk, lagged price risk of sorghum and lagged area cultivated under millet as evident by their respective parameter estimates which were within the acceptable margin of $10 \%$ degree of freedom.

The positive significant of lagged yield indicated that high yield of millet owing to use of improved seed varieties encouraged farmers to increase the current acreage allocated to millet in the studied area. In addition, this showed a shift in the area allocated to the competing crops to the cultivation of millet. Thus, innovational support viz. improved practices and seed varieties have increased the productivity of millet, thus impacting positively on the farmers' current acreage allocation decisions. The marginal and elasticity implications of a unit increase in the lagged millet yield will encouraged the farmers to increase the current acreage allocated to millet production by 143 hectares and $0.39 \%$ respectively.

Despite the use of drought resistant seed varieties, weather vagaries viz. dry-spell turn-out to be a disincentive, thus forced the farmers to decrease the current acreage allocated to millet production as evident by the negative significant of the weather index parameter. Climate change continued to be a threat to agricultural production in the Northern region of the country where the crop is majorly produced, thus affecting millet food defense. Therefore, the marginal and elasticity implications of an increase in the weather index would lead to a decrease in the current area cultivated under millet by 2.01 million hectares and $0.532 \%$ respectively.

The negative significant of lagged price of maize indicated that maize is a competing crop with millet, thus affected the current acreage allocated to millet production. Thus, an increase in the lagged price of maize forced millet farmers to shift to the cultivation of maize in the subsequent year by decreasing the area allocated to millet production. Therefore, the marginal and elasticity implications of a unit increase in the lagged maize price will lead to a decrease in the current area cultivated under millet production by 100 hectares and $0.543 \%$ respectively.

Also, the coefficient of the lagged sorghum price indicated it to be a competing crop, but it did not pose a threat to the farmers to shift area cultivated under millet as indicated by the non-significant of the coefficient. However, the farmers are apprehensive of lagged sorghum price risk as downward fluctuation of sorghum price had a pull-down effect on millet price, thus affecting farmers' current acreage allocation decision. Therefore, the marginal and elasticity implications of a fluctuation in the lagged sorghum 
price risk will lead to a decrease in the current acreage by 164 hectares and $0.151 \%$ respectively.

The positive significant of the lagged millet price coefficient indicated that the farmers received remunerative price, thus an incentive which encouraged them to increase the current acreage cultivated under millet production. In addition, this showed that market imperfection is in favor of millet production in the country and also government pricing policy on millet production is in the right direction. The marginal and elasticity implications of a unit increase in the lagged millet price will encourage farmers to increase the current area under millet by 186 hectares and $0.886 \%$ respectively. The elasticity estimate been 0.886 indicated the acreage responsive of millet to its price change in the preceding period. This result contradicts the outcome of Sadiqet al.(2017) on acreage response of cereal (pearl millet-Bajra) production in India's Rajasthan and this may be attributed to differences in the nation's policy on millet production. Despite that Bajra production has received adequate harnessing productivity enhancement opportunities in India as an important food crop especially for the semi-arid and arid regions of the country, animal feeds and industrial precursor; government pricing policy at the time of that study did not favour millet production. Furthermore, the impact of the Nigerian price policy on millet production is high as indicated by the long-run elasticity (LRE) estimate which is 4.44 .

It was observed that 14.35 years, a very long period is required for the price effect on millet production to materialize. This revealed that millet production is highly constrained with institutional and technological challenges, thus the need for more time for the price adjustment. Sadiq et al.(2017) reported that the smaller the time for adjustment, the more effective is the price policy instruments in bringing desired change in the supply of a crop. This finding is contrary to finding of Sadiq et al.(2017) who found an indeterminate years for pearl millet (Bajra) in India's Rajasthan state.

The empirical evidence revealed that the farmers were risk averse to yield fluctuation as evident by the negative significant of the lagged millet yield risk, thus a disincentive to farmers' current acreage allocation decision. In addition, declined in yield which may be attributed largely to the devastating effect of weather vagaries discouraged the farmers from increasing the current acreage cultivated under millet production in the area. Therefore, the marginal and elasticity implications of lagged millet yield risk will lead to a decrease in the current area cultivated under millet production by 344 hectares and $0.110 \%$ respectively.

The estimated adjustment coefficient was low (0.188), implying low adjustment in the area cultivated under millet by the farmers in the study area. Since the adjustment coefficient is less than unity, it shows that the farmers partially adjust the area under millet in the current year, thus, the adjustment continues and gives rise to the lags, which are distributed over time.

It is worth to mention that the economic policies were in the right direction but did not exert impact on farmers' acreage allocation decision in the studied area as indicated by the non-significant of the time trend variable. This may be due to the vicious chain of poverty which affects the business going concern and livelihood of the farmers. However, technology had positive impact on the current acreage allocation decision of the farmers as evident by the significant of the managerial efficiency parameter. 
Table 8. Farmers' acreage response

\begin{tabular}{|c|c|c|c|c|c|c|c|c|}
\hline Items & Linear & t-stat & Exponential (+) & t-stat & Semi-log & t-stat & Double-log & t-stat \\
\hline Intercept & $1.782 e+6(612158)$ & $2.912 * * *$ & $14.5484(0.1589)$ & $91.52 * * *$ & $-3.445 e+7(7.109 e+6)$ & $4.845^{* * *}$ & $0.9214(2.2069)$ & $0.417^{\mathrm{Ns}}$ \\
\hline $\mathrm{MP}_{\mathrm{t}-1}$ & $-60.616(42.266)$ & $1.434^{\mathrm{NS}}$ & $-2.61 e-5(1.24 e-5)$ & $2.099 * *$ & $-1.051 e+6(995133)$ & $1.056^{\mathrm{NS}}$ & $-0.3867(0.3089)$ & $1.252^{\mathrm{Ns}}$ \\
\hline $\mathrm{SP}_{\mathrm{t}-1}$ & $-49.015(67.580)$ & $0.725^{\mathrm{NS}}$ & $-2.58 e-5(1.838 e-5)$ & $1.401^{\mathrm{NS}}$ & $1.388 \mathrm{e}+6(896807)$ & $1.548^{\mathrm{NS}}$ & $0.4375(0.2783)$ & $1.572^{\mathrm{Ns}}$ \\
\hline$M L P_{t-1}$ & $95.007(101.58)$ & $0.935^{\mathrm{NS}}$ & $4.84 e-5(2.747 e-5)$ & $1.760 *$ & $283473(929840)$ & $0.304^{\mathrm{NS}}$ & $0.0387(0.2886)$ & $0.134^{\mathrm{NS}}$ \\
\hline $\mathrm{MPR}_{\mathrm{t}-1}$ & $-85.83(49.83)$ & $1.722 *$ & $-1.87 e-5(1.514 e-5)$ & $1.235^{\mathrm{NS}}$ & $165105(230988)$ & $0.714^{\mathrm{NS}}$ & $0.0455(0.0717)$ & $0.635^{\mathrm{N} s}$ \\
\hline $\mathrm{SPR}_{\mathrm{t}-1}$ & $100.37(80.705)$ & $1.244^{\mathrm{NS}}$ & $4.256 e-5(1.912 e-5)$ & $2.226^{* *}$ & $-274616(265046)$ & $1.036^{\mathrm{NS}}$ & $-0.0897(0.0822)$ & $1.091^{\mathrm{Ns}}$ \\
\hline MLPRt-1 $_{\mathrm{t}}$ & $-8.649(100.40)$ & $0.086^{\mathrm{NS}}$ & $-2.302 e-5(2.501 e-5)$ & 0.920 & $-29165.6(192402)$ & $0.151^{\mathrm{NS}}$ & $0.0149(0.0597)$ & $0.250^{\mathrm{N} s}$ \\
\hline$Y_{t-1}$ & $85.52(37.73)$ & $2.266 * *$ & $3.81 e-5(1.09 e-5)$ & $3.505^{* * *}$ & $510587(434585)$ & $1.175^{\mathrm{NS}}$ & $0.2597(0.1349)$ & $1.926 *$ \\
\hline $\mathrm{YR}_{\mathrm{t}-1}$ & $-237.98(74.42)$ & $3.197 * *$ & $-8.94 e-5(2.54 e-5)$ & $3.525^{* * *}$ & $-115808(72076.1)$ & $1.607^{\mathrm{NS}}$ & $-0.0345(0.0223)$ & $1.544^{\mathrm{Ns}}$ \\
\hline $\mathrm{T}_{\mathrm{t}}$ & $15861.2(14015.5)$ & $1.132^{\mathrm{NS}}$ & $0.002731(0.003839)$ & $0.711^{\mathrm{NS}}$ & $-84353.2(42346.4)$ & $1.992 *$ & $-0.0122(0.0131)$ & $0.929^{\mathrm{NS}}$ \\
\hline$W I_{t}$ & $-1.325 e+6(330907)$ & $4.00 * * *$ & $-0.523270(0.109509)$ & $4.778 * * *$ & $-190617(466738)$ & $0.408^{\mathrm{NS}}$ & $-0.1055(0.1448)$ & $0.728^{\mathrm{NS}}$ \\
\hline$A_{t-1}$ & $0.7055(0.0767)$ & $9.188 * * *$ & $2.1087 e-7(2.088 e-8)$ & $10.10 * * *$ & $2.167 e+6(376408)$ & $5.756 * * *$ & $0.7841(0.1168)$ & $6.711^{\mathrm{NS}}$ \\
\hline $\mathrm{R}^{2}$ & 0.8498 & & 0.8813 & & 0.8533 & & 0.8626 & \\
\hline F-stat & $97.66[2.62 \mathrm{e}-25]^{* * *}$ & & $78.17[1.8 \mathrm{e}-23]^{* * *}$ & & $16.39[5.52 \mathrm{e}-10]^{* * *}$ & & $17.69[2.09 \mathrm{e}-10]^{* * *}$ & \\
\hline D-W stat & & & $1.934[0.201]^{\mathrm{NS}}$ & & & & & \\
\hline Autocorrelation & & & $0.046[0.829]^{\mathrm{NS}}$ & & & & & \\
\hline Arch effect & & & $0.155[0.692]^{\mathrm{NS}}$ & & & & & \\
\hline Heteroscedasticity & & & $7.761[0.734]^{\mathrm{NS}}$ & & & & & \\
\hline Normality & & & $0.442[0.801]^{\mathrm{NS}}$ & & & & & \\
\hline RESET test & & & $0.889[0.353]^{\mathrm{NS}}$ & & & & & \\
\hline Chow test & & & $0.793[0.378]^{\mathrm{NS}}$ & & & & & \\
\hline CUSUM test & & & $-1.131[0.264]^{\mathrm{NS}}$ & & & & & \\
\hline
\end{tabular}

Source: Authors' own computation, 2020

Note: $* * * * *$ Ns means significant at $1 \%, 5 \%, 10 \%$ probabilities and Non-significant respectively.

Values in () and \{ \} are standard error and probability level respectively. 
Table 9. Short-run and long-run elasticity estimates

\begin{tabular}{lllll}
\hline Variables & Mean & Marginal Effect & SRE & LRE \\
\hline $\mathrm{MP}_{\mathrm{t}-1}$ & 20809.2 & $-1.00 \mathrm{E}+02$ & $-5.43 \mathrm{E}-01$ & -2.72303 \\
$\mathrm{SP}_{\mathrm{t}-1}$ & 18356.96 & $-9.91 \mathrm{E}+01$ & $-4.73 \mathrm{E}-01$ & -2.36911 \\
$\mathrm{MLP}_{\mathrm{t}-1}$ & 18331.15 & $1.86 \mathrm{E}+02$ & $8.86 \mathrm{E}-01$ & 4.441825 \\
$\mathrm{MPR}_{\mathrm{t}-1}$ & 3156.401 & $-7.20 \mathrm{E}+01$ & $-5.90 \mathrm{E}-02$ & -0.29579 \\
$\mathrm{SPR}_{\mathrm{t}-1}$ & 3547.603 & $1.64 \mathrm{E}+02$ & $1.51 \mathrm{E}-01$ & 0.756693 \\
$\mathrm{MLPR}_{\mathrm{t}-1}$ & 3141.25 & $-8.86 \mathrm{E}+01$ & $-7.23 \mathrm{E}-02$ & -0.3624 \\
$\mathrm{Y}_{\mathrm{t}-1}$ & 10364.21 & $1.46 \mathrm{E}+02$ & $3.94 \mathrm{E}-01$ & 1.97625 \\
$\mathrm{YR}_{\mathrm{t}-1}$ & 1225.127 & $-3.44 \mathrm{E}+02$ & $-1.10 \mathrm{E}-01$ & -0.54896 \\
$\mathrm{~T}_{\mathrm{t}}$ & 27 & $1.05 \mathrm{E}+04$ & $7.37 \mathrm{E}-02$ & 0.369542 \\
$\mathrm{WI}_{\mathrm{t}}$ & 1.016113 & $-2.01 \mathrm{E}+06$ & $-5.32 \mathrm{E}-01$ & -2.66459 \\
$\mathrm{~A}_{\mathrm{t}-1}$ & 3795918 & $8.12 \mathrm{E}-01$ & $8.00 \mathrm{E}-01$ & 4.011441 \\
\hline
\end{tabular}

Source: Authors' own computation, 2020

Note: Average Area $=3848669$

\section{Production Forecast of Millet}

The non-significant of all the unit root tests viz. ADF, KPSS and ADF-GLS for the entire variables at level indicate the presence of trend but after the first difference the tau-statistics of the unit root test were within the acceptable margin of $5 \%$, thus indicating the absence of trend in all the variables (Table 10). The absence of trend in the variables revealed their plausibility for further analysis. Furthermore, the ARIMA results at different levels for all the variables showed ARIMA $(1,1,1)$, ARIMA $(1,1,0)$ and ARIMA $(1,1,0)$ to be the best fit to forecast production, area and yield, respectively (Table 9). In addition, all the chosen ARIMAs had their residual devoid of serial correlation and Arch effect as evident by their respective t-statistics which were not different from zero at $10 \%$ probability level. However, their residuals were not normally distributed as indicated by their respective $\mathrm{Chi}^{2}$ test statistics which were within the acceptable margin of $10 \%$ error gap. Non-normality is not considered a serious problem as data in their natural form are mostly not normally skewed, thus the selected ARIMAs are reliable for prediction with certainty and consistency.

Using the one-step-ahead forecast, the reliability of the predictive power of the chosen ARIMAs and how closely they could track the path of the actual observations were verified (Table 11).

Table 10. ARIMA model

\begin{tabular}{|c|c|c|c|c|}
\hline \multicolumn{2}{|l|}{ Items } & Production & Area & Yield \\
\hline \multirow[t]{2}{*}{ ADF } & Level & $-1.765(0.393)^{\mathrm{ns}}$ & $-1.858(0.349)^{\mathrm{ns}}$ & $-2.027(0.275)^{\mathrm{ns}}$ \\
\hline & $1^{\text {st }}$ Diff & $-3.753(0.003)^{\mathrm{st}}$ & $-8.038(4.4 \mathrm{e}-9)^{\mathrm{st}}$ & $-9.790(5.1 \mathrm{e}-11)^{\mathrm{st}}$ \\
\hline \multirow[t]{2}{*}{ KPSS } & Level & $0.657(0.462)^{\mathrm{ns}}$ & $0.266^{\mathrm{ns}}$ & $0.312^{\mathrm{ns}}$ \\
\hline & $1^{\text {st }}$ Diff & $0.144(0.462)^{\mathrm{st}}$ & $0.071^{\text {st }}$ & $0.040^{\text {st }}$ \\
\hline \multirow[t]{2}{*}{ ADF-GLS } & Level & $-1.712^{\text {ns }}$ & $-1.973^{\mathrm{ns}}$ & $-1.862^{\mathrm{ns}}$ \\
\hline & $1^{\text {st }}$ Diff & $-3.757^{\text {st }}$ & $-5.115^{\mathrm{st}}$ & $-5.141^{\mathrm{st}}$ \\
\hline \multicolumn{2}{|c|}{ ARIMA $(1,1,1)($ AIC $)$} & $1727.24^{+}$ & 1693.67 & 1038.60 \\
\hline \multicolumn{2}{|c|}{ ARIMA $(1,1,0)(A I C)$} & 1728.96 & $1691.68^{+}$ & $1038.35^{+}$ \\
\hline \multicolumn{2}{|c|}{ ARIMA $(0,1,1)(A I C)$} & 1729.30 & 1691.72 & 1039.17 \\
\hline \multicolumn{2}{|c|}{ Autocorrelation test } & $5.55[0.135]^{\mathrm{NS}}$ & $3.378[0.496]^{\mathrm{NS}}$ & $4.719[0.317]^{\mathrm{NS}}$ \\
\hline \multicolumn{2}{|c|}{ Arch LM test } & $0.009[0.922]^{\mathrm{NS}}$ & $1.033[0.309]^{\mathrm{NS}}$ & $0.703[0.401]^{\mathrm{NS}}$ \\
\hline \multicolumn{2}{|c|}{ Normality test } & $75.1[4.7 \mathrm{e}-17]^{* * *}$ & $8.940[0.011]^{* *}$ & $30.8[1.9 \mathrm{e}-7]^{* * *}$ \\
\hline
\end{tabular}

Source: Authors' computation, 2020; ******NS, nst, st: means significant at 1, 5, 10\%, Non-significant, non-stationary and stationary respectively.Note: ADF-GLS and KPSS tau critical levels at $5 \%$ probability are -3.03 and 0.149 respectively. 
Table 11. One step ahead forecast of millet production

\begin{tabular}{lcccccc}
\hline \multirow{2}{*}{ Period } & \multicolumn{2}{c}{ Production } & \multicolumn{2}{c}{ Area } & \multicolumn{2}{c}{ Yield } \\
& Actual & Forecast & Actual & Forecast & Actual & Forecast \\
\hline 2014 & 1398667 & 1445645 & 1511222 & 1439317 & 9255 & 7144.93 \\
2015 & 1485387 & 929802.5 & 1591803 & 1477681 & 9331 & 8427.98 \\
2016 & 1552576 & 1795937 & 1914545 & 1553121 & 8109 & 9353.05 \\
2017 & 1500000 & 1306704 & 2271719 & 1853045 & 6603 & 8491.8 \\
2018 & 2240744 & 1670739 & 2795829 & 2206974 & 8015 & 7064.73 \\
\hline
\end{tabular}

Source: Authors' computation, 2020

Empirical evidences showed the relative mean absolute prediction error (RMAPE) and the Theil's inequality coefficient to be within the plausible margin of $5 \%$ and 1 respectively, thus indicating the reliability of the chosen ARIMAs for prediction (Table 12). Given that the predictive error associated with the estimated equations in tracking the actual data (ex-post prediction) are insignificant and low, thus the chosen ARIMAs can be used for ex-ante projection with high projection validity and consistency.

Table 12. Validation of models

\begin{tabular}{lllllll}
\hline Variable & $\mathbf{R}^{\mathbf{2}}$ & RMSE & RMSPE & MAPE & RMAPE (\%) & Theil's U \\
\hline Production & 0.868475 & 382143.3 & 83172.21 & 215105 & 12.01067 & 1.0058 \\
Area & 0.852944 & 364880.5 & 55519.13 & 296615 & 13.10778 & 1.0086 \\
Yield & 0.969028 & 1169.075 & 186.2416 & -255.912 & -4.4826 & 1.0057 \\
\hline
\end{tabular}

Source: Authors' computation, 2020

For the period 2019 to 2030, the one-step-ahead out of the sample forecast results showed that the production of millet will be characterized by slight increase and decrease till the end of the forecasted period (Table 13 \& Figure 5). The yield will witness a slight incremental trend which will last till the end of the forecasted period while the area will be marked by a decreasing trend till the end of the study period (Table 13 \& Figure 6-7). The marginal incremental effect of yield will be responsible for the marginal rise in the production trend while the marginal plummeting effect of the area will be responsible for the decline in the production of the millet. It is worth to mention that fluctuation owing either to area expansion or high productivity will not make the production to exceed the upper boundary while a contraction in area or low productivity will not make the production to go below the lower boundary points. In addition, the upper and lower limits are referred to optimistic and pessimistic production margins. Therefore, it can be inferred that the food defense of millet production in the future will be affected owing to poor performance of yield. Thus, there is need for enhancement of the innovative millet practices as limited available land will continue to shrink due to pressure on limited arable land for other purposes viz. increase urbanization, industrialization etc.

Table 13. Out of sample forecast of the variables

\begin{tabular}{ccccccc}
\hline Year & Forecast & $\begin{array}{c}\text { Production } \\
\text { Pessimistic }\end{array}$ & Optimistic & Forecast & $\begin{array}{c}\text { Area } \\
\text { Pessimistic }\end{array}$ & Optimistic \\
\hline 2019 & 1997547.84 & 318494.88 & 3676600.79 & 2715354.40 & 1462846.97 & 3967861.83 \\
2020 & 2194000.08 & 15141.06 & 4403141.23 & 2691848.28 & 1001926.63 & 4381769.93 \\
2021 & 2011257.46 & 743420.47 & 4765935.40 & 2662974.17 & 621344.44 & 4704603.90 \\
2022 & 2155568.79 & 964215.73 & 5275353.31 & 2634605.87 & 294035.66 & 4975176.07 \\
2023 & 2017797.49 & 1497835.99 & 5533430.97 & 2606189.90 & 712.62 & 5211667.18 \\
2024 & 2123321.24 & 1693463.17 & 5940105.66 & 2577778.43 & 268048.96 & 5423605.82 \\
2025 & 2019004.05 & 2120413.17 & 6158421.28 & 2549366.54 & 518035.82 & 5616768.89 \\
2026 & 2095673.78 & 2307810.16 & 6499157.73 & 2520954.68 & 753061.31 & 5794970.67 \\
2027 & 2016243.07 & 2664957.96 & 6697444.10 & 2492542.82 & 975800.33 & 5960885.97 \\
2028 & 2071448.32 & 2848447.75 & 6991344.38 & 2464130.96 & 1188214.54 & 6116476.47 \\
\hline
\end{tabular}


Continuing Table 13

\begin{tabular}{|c|c|c|c|c|c|c|}
\hline 2029 & 2010530.63 & 3156276.35 & 7177337.61 & 2435719.11 & 1391793.30 & 6263231.51 \\
\hline 2030 & 2049768.47 & 3336739.85 & 7436276.79 & 2407307.25 & 1587698.98 & 6402313.47 \\
\hline Year & Forecast & $\begin{array}{c}\text { Yield } \\
\text { Pessimistic }\end{array}$ & Optimistic & & & \\
\hline 2019 & 7665.74 & 3605.39 & 11726.08 & & & \\
\hline 2020 & 7805.98 & 2797.76 & 12814.19 & & & \\
\hline 2021 & 7810.17 & 1842.30 & 13778.04 & & & \\
\hline 2022 & 7852.18 & 1100.11 & 14604.25 & & & \\
\hline 2023 & 7883.68 & 419.15 & 15348.20 & & & \\
\hline 2024 & 7918.10 & 193.93 & 16030.12 & & & \\
\hline 2025 & 7951.70 & 760.52 & 16663.92 & & & \\
\hline 2026 & 7985.53 & 1287.93 & 17259.00 & & & \\
\hline 2027 & 8019.30 & 1783.37 & 17821.98 & & & \\
\hline 2028 & 8053.09 & 2251.65 & 18357.83 & & & \\
\hline 2029 & 8086.87 & 2696.58 & 18870.32 & & & \\
\hline 2030 & 8120.66 & 3121.14 & 19362.45 & & & \\
\hline
\end{tabular}

Source: Authors' computation, 2020

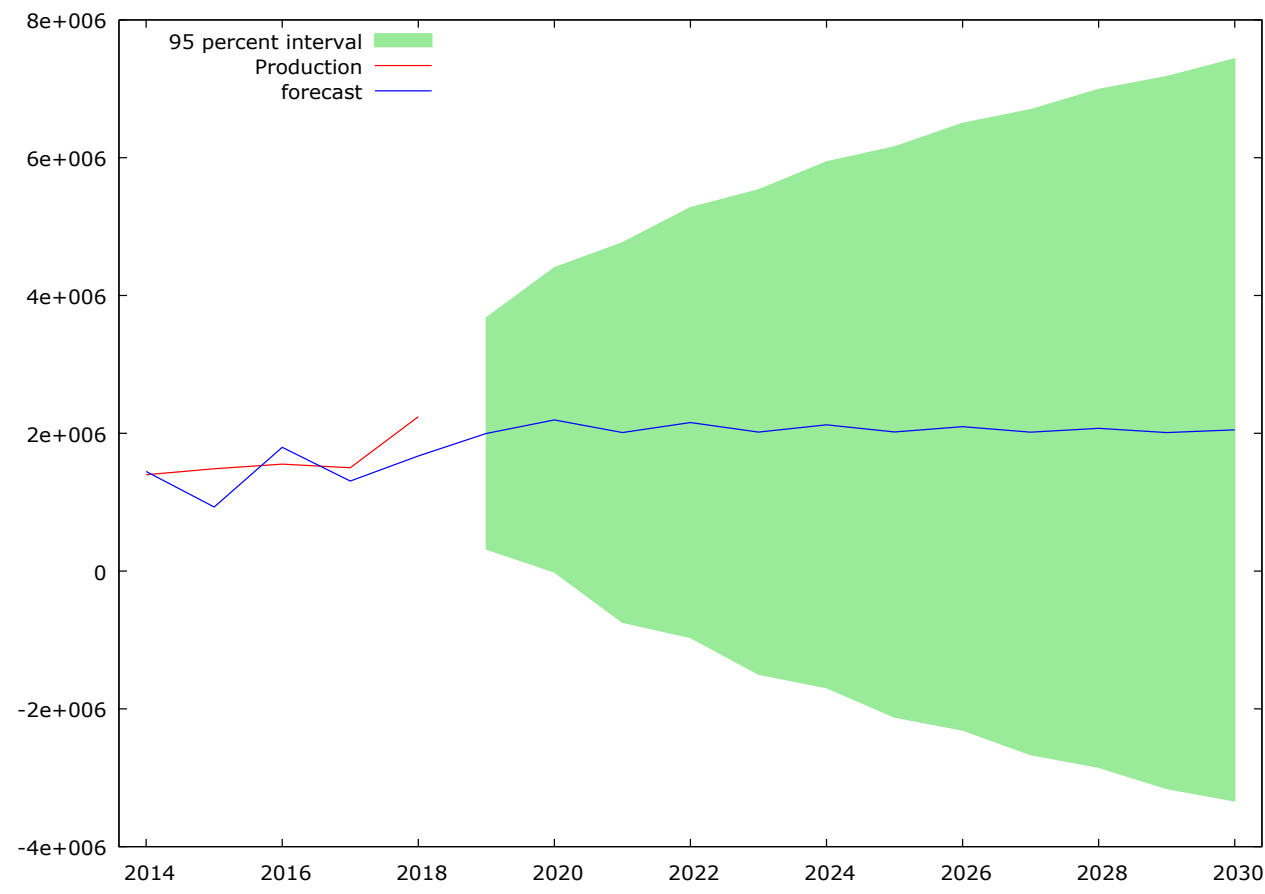

Figure 5. Productionforecast of millet 

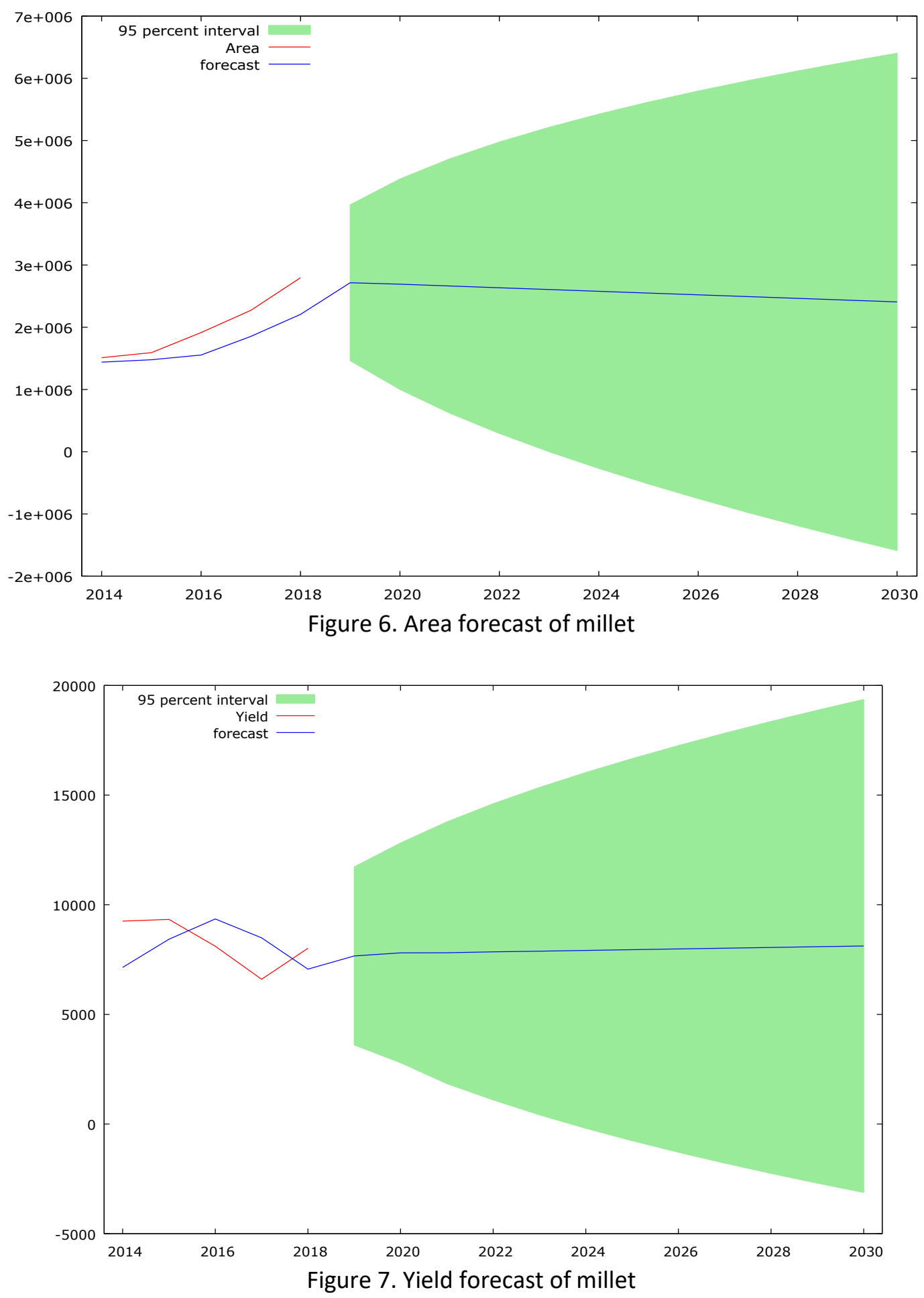

In conclusion, the empirical evidence showed the production trend pattern throughout the economic reforms to be driven majorly by area effect changes as productivity performance was low. In addition, it was observed that the production performance of millet was poor as its growth was majorly determined by area other than yield. Instability in the production of millet was high which owed to the effect of price shock, thus triggering fluctuation in area and yield. Beside, production risk and uncertainty were the major sources that caused variability in the production level between the regime periods. It was observed that differences in average production level between the regime periods owed majorly to area effect as the yield exerted a marginal effect. Furthermore, based on the results, it was inferred that the acreage allocation decisions of the farmers was governed by both institutional and non-institutional factors; though the effect of price 
factors predominates. Poor performance of yield will marred the future food security of millet production as available land will continue to shrinking owing to demand for land for other purposes. Thus, based on the foregoing, the study calls for a policy attention that will encourage massive production of millet to cater for the high human, animal and industrial demands. Otherwise, the country will be a millet market destination for foreign nations especially the near neighbors to explore their comparative advantage. A critical reliance on millet importation will expose the country to risks from global food price spikes and shortages; and geopolitical and environmental threats. A long-term domestic selfsufficiency in millet production capable of feeding the population should be a key strategic goal of Nigeria.

\section{ÖZET}

Amaç: Darı, özellikle Nijerya'da yoğun tarımın önemli bileşenlerinden birisi olması nedeniyle, gıda güvenliği ve ekonomik çeşitlendirme potansiyellerinin keşfedilmesine ihtiyacı vardır.

Yöntem ve Bulgular: Nijerya'da darı üretiminin gıda güvenliği eğilimini incelemek için, FAO veri tabanından 1961'den 2018'e kadar kayıtlı üretim, alan ve verimi kapsayan zamanı serisi verileri kullanılmıştır. Toplanan veriler hem tanımlayıcı hem de çıkarımsal istatistikler kullanılarak analiz edilmiştir. Elde edilen bulgular, büyümenin verimlilik dışındaki alan tarafından yönlendirildiği için darı üretiminde zayıf performans gösterdiğini bildirmiştir. Fiyatlardaki değişikliğin alan ve verimde yüksek dalgalanmayı tetikleyerek darı üretiminde yüksek istikrarsızlığa neden olduğu görülmüştür. Ek olarak, üretim riski ve belirsizliği, rejim değişiklikleri arasındaki üretim değişkenliğinin ana kaynakları olduğu tespit edilmiştir. Rejim değişiklikleri arasındaki ortalama üretim seviyesindeki artışın büyük ölçüde alan genişlemesine bağı olduğu gözlemlenmiştir. Geçmiş yıllardaki kanıtlar, çiftçilerin darı için mevcut arazi tahsisi kararının hem kurumsal hem de kurumsal olmayan faktörler tarafından yönetildiğini göstermiştir. Ayrıca, darıdaki gıda güvensizliğinin ülkeyi savaşa sürükleyebileceğini, darı ithalatına kritik bir bağımlılık ülkeyi küresel gıda fiyatlarındaki ani artışlar ve kıtlıklardan kaynaklanan risklere maruz bırakacağını ve jeopolitik ve çevresel tehditlere neden olabileceğini tahmin etmiştir.

Genel Yorum: Eldeki sonuçlara göre darı üretiminin büyüme performansının olumlu olmadığı söylenebilir. Çalışma sonuçları kilit bir stratejik gıda hedefi olarak ülke nüfusunu besleyebilecek darı üretiminde uzun vadeli yerli, kendi kendine yeterlilik ihtiyacını önermektedir.

Çalışmanın Önemi ve Etkisi: Bu araştırmanın sonucu, politika yapıcılar için gıda güvenliği için darı üretiminin zorluklarını ele alma, hayvan yemi olarak hayvancllık üretimini teşvik etme ve Afrika'daki bol kurak bölgelere inracatla kazanç sağlamaya katkı sağlayabilecektir.

Anahtar Kelimeler: Büyüme, eğilim, üretim, tahmin, darı, Nijerya.

\section{CONFLICT OF INTEREST}

The authors declare no conflict of interest for this study.

\section{AUTHOR'S CONTRIBUTIONS}

The contribution of the authors is equal.

\section{REFERENCES}

Ahmed SI, Joshi MB (2013) Analysis of instability and growth rate of cotton in three district of Marathwada. Int. J. Stat. Math. 6(3): 121-124.

Alahira J (2018) Agricultural production-millet production. Available online:

https://www.agriculturenigeria.com/productio $\mathrm{n}$ /crop-production/general-crops/millet/

(Accessed on 6/7/2020)

Ali A, Hudu MI, Ojeleye OA (2018) Economics of millet production in Funakaye Local Government, Gombe State, Nigeria. PAT 14(2): 50-57.

Anonymous (2018a) Global millet market analysis, growth and trends forecast. Available online: https://www.businesswire.com/news/home/201805 25005227/en/Global-Millet-Market-AnalysisGrowth-Trends-Forecast (Accessed on 6/7/2020)

Anonymous (2018b) 2017 to 2022 analysis of size, share and growth in demand for millet. Global Millet Market Report. Available online: https://www.fooddive.com/pressrelease/20180619-global-millets-market-report2017-to-2022-analysis-size-share-growth- d/ (Accessed on 6/7/2020)

Ayalew B (2015) Supply response of maize in Ethiopia: co-integration and vector error correction approach. T. Agric. Econ. 8 (1): 13-20.

Baiyegunhi LS, Fraser GCG (2009) Profitability in sorghum production in three villages of Kaduna State Nigeria. J. Appl. Sc. Res. 5: 1685-1691.

Boyal VK, Pant DC, Mehra J (2015) Growth, instability and acreage response function in production of cumin in Rajasthan. The Bioscan 10(1): 359-362. 
Coppock JD (1962) International economic instability. McGraw-Hill, New York, pp 523-525.

Cuddy JDA, Valle, PAD (1978) Measuring the instability of time series data. Oxf. Bull. Econ. Stat. 40: 53-78.

FAO (2018) FAO Statistical Pocketbook: World Food and Agriculture 2018; Food and Agriculture Organization of the United Nations: Rome, Italy, 2018. Available online: http://www.fao.org/3/CA1796EN/ca1796en.pdf

Gujarati D, Porter D, Gunasekar S (2012) Basic econometrics. McGraw Hill, New Delhi.

Hazell PBR (1982) Instability in Indian food grain production. Res. Rep. 30, Washington, D.C., USA: International Food Policy Research Institute.

Isah MA, Shadi S, Sadiq MS, Goni M, Makama SA (2019) Trends, growth and instability of millet production in Nigeria. Nig. J. Agric. Ext. 20(1): 26-32.

Kumar NS, Joseph B, Muhammed JPK (2017) Growth and Instability in area, production, and productivity of cassava (Manihot esculenta) in Kerala. Int. J. Adv. Res. Id. Inn. Tech. 4(1): 446-448.

Lu H, Zhang J, Liu KB, Wu N, Li Y, Zhou K, Ye M, Zhang T, Zhang H, Yang X, Shen L, Xu D, Li Q (2009) Earliest domestication of common millet (Panicum miliaceum) in East Asia extended to 10,000 years ago. PNAS 106: 7367-7372.

Paul RK (2014) Forecasting wholesale price of pigeon pea using long memory time-series models. Agric. Econ. Res. Rev. 27(2): 167-176.
Sadiq MS, Singh IP, Karunakaran N (2017) Supply response of cereal crop farmers to price and nonprice factors in Rajasthan state of Nigeria. J. Agric. Econ. R. Dev. 3(2): 203-210.

Sadiq MS, Singh IP, Ahmad MM, Hafizu MS (2019) Roadmap to self-sufficiency of cowpea production in Nigeria. Ife J. Agric. 31(3): 60-76.

Sandeep MV, Thakare SS, Ulemale, DH (2016) Decomposition analysis and acreage response of pigeon-pea in western Vidarbha. Ind. J. Agric. Res. 50(5): 461-465.

Shimla R (2014) Growth and instability in agricultural production in Haryana: A district level analysis. Int. J. Sci. Res. Pub. 4: 1-12.

Stalling JL (1960) Weather indexes. J. Farm Econ. 42: 180-186.

Umar SM, Suhasini K, Jainuddin SM, Makama SA (2019) Sources of growth and instability in cassava production in Nigeria: An evidence from Hazell's Decomposition Model. SKUAST. J. Res. 21(1): 86-95.

Umar SM, Suhasini K, Sadiq MS, and Aminu A (2017) Growth and instability in yam production in Nigeria: An inter zone and state level analysis. Dutse J. Agric. Food Sec. 4(1): 10-24. 